(2) Open Access Full Text Article

ORIGINAL RESEARCH

\title{
Jawbone Cavitation Expressed RANTES/CCL5: Case Studies Linking Silent Inflammation in the Jawbone with Epistemology of Breast Cancer
}

This article was published in the following Dove Press journal: Breast Cancer: Targets and Therapy

\author{
Johann Lechner $\mathbb{D}^{1}$ \\ Tilman Schulz ${ }^{2}$ \\ Beatrice Lejeune (iD $^{3}$ \\ Volker von Baehr ${ }^{4}$ \\ 'Clinic Integrative Dentistry Munich, \\ Munich, Germany; ${ }^{2}$ Klinikum Bayreuth, \\ Bayreuth, Germany; ' ${ }^{2}$ abo'Life France, \\ Nantes, France; ${ }^{4}$ Institute for Medical \\ Diagnostics, Berlin, Germany
}

Correspondence: Johann Lechner Clinic Integrative Dentistry Munich, Praxisklinik Gruenwalder Str. I0A, Munich, 81547, Germany

Tel +4989 6970I29

Fax +49896925830

Email drlechner@aol.com
Background: The role of signaling pathways as part of the cell-cell communication within cancer progression becomes a crucial area. Chemokine RANTES (regulated upon activation, normal T-cell expressed and secreted), also known as the chemokine $\mathrm{C}-\mathrm{C}$ motif ligand 5 (CCL5) $(\mathrm{R} / \mathrm{C})$, is a protein on which cancer research focus due to its link with aggressive cancer development.

Objective: Research on fatty-degenerative osteonecrosis in jawbone (FDOJ) shows striking overexpression of $\mathrm{R} / \mathrm{C}$ in these areas. Here we try to elucidate a potential link between jawbone-derived $\mathrm{R} / \mathrm{C}$ and breast cancer $(\mathrm{BC})$ and compare these findings by immunohistochemical staining.

Methods: Thirty-nine FDOJ samples extracted from 39 BC patients and samples from 19 healthy control were analyzed for R/C expression using bead-based Luminex ${ }^{\circledR}$ analysis. R/C levels from $5 \mathrm{BC}$ patients were measured in serum before and after FDOJ surgery. Bone density, histology, $\mathrm{R} / \mathrm{C}$ expression, and immunohistochemistry were analysed in 4 clinical case studies. The $\mathrm{R} / \mathrm{C}$ staining of two FDOJ BC patients is compared with the immunohistochemical staining of $\mathrm{BC}$ cell preparations.

Results: A high overexpression of $\mathrm{R} / \mathrm{C}$ was seen in all FDOJ samples. $\mathrm{R} / \mathrm{C}$ levels in serum were statistically downregulated after FDOJ surgery $(\mathrm{p}=0.0241)$.

Discussion: $\mathrm{R} / \mathrm{C}$ induced "silent inflammation" in $\mathrm{BC}$ is widely discussed in scientific papers along with $\mathrm{R} / \mathrm{C}$ triggering of different signaling pathways, which might be a key point in the development of $\mathrm{BC}$.

Conclusion: Hypothesis that FDOJ may serve as a trigger of $\mathrm{BC}$ progression through $\mathrm{R} / \mathrm{C}$ overexpression was set by the authors, who thus inspire clinicians to make aware of FDOJ throughout the dental and medical community in $\mathrm{BC}$ cases.

Keywords: chemokine RANTES/CCL5, osteonecrosis of the jawbone, breast cancer, beadbased Luminex $^{\circledR}$ analysis, hyperactivated signaling pathways

\section{Background}

Oncology is making rapid progress - but not in all areas. Anomalies in genomic DNA trigger cancer - this has been the paradigm of researchers and oncologists for the last 50 years. However, the somatic mutation theory for carcinogenesis might be overestimated, because inflammation plays a more substantial role than previously thought. Research takes into account modern knowledge of cell to cell communication for a more plausible cancer hypothesis. ${ }^{1}$ Because cell-to-cell communication is vital for morphogenesis, cell differentiation, homeostasis, cell growth, and cellular interaction. With all its cross-talk among immunocompetent 
cells within this immune computing network, signaling pathways are not fully understood. However, the signaling pathways of the $T$ cells released cytokines affect cancer progression through paracrine cell communication. ${ }^{2,3}$ Research on signaling pathways and cell communication will be an important area to advance and promote the fight against cancer. ${ }^{3}$ An overview shows the extensive studies that also attempt to explain metastasis in the context of complex and dynamic tumor microenvironment consisting of cells, blood vessels, extracellular matrix (ECM), cytokines, and chemokines. $^{4,5}$ In particular, inflammatory processes mediated by tumor microenvironment have been highlighted in BC progression. ${ }^{6}$ An example of a chemokine associated with aggressive $\mathrm{BC}$ is RANTES (regulated upon activation, normal T-cell expressed and secreted), also known as chemokine C-C motif ligand 5 (CCL5). ${ }^{7}$ In particular, RANTES/CCL5 (R/C) mediates the migration and chemotaxis of cells, including memory T lymphocytes, ${ }^{8}$ monocytes, ${ }^{9}$ dendritic cells, ${ }^{10}$ eosinophils, basophils, ${ }^{11}$ and mast cells. ${ }^{12}$ The role of $\mathrm{R} / \mathrm{C}$ in $\mathrm{BC}$ invasion has been extensively studied. ${ }^{13}$ Elevated levels of $\mathrm{R} / \mathrm{C}$ and its receptor CCR5 have been detected in more than $58 \%$ of basal $\mathrm{BC}$ patients. ${ }^{13}$ In addition to a role in $\mathrm{BC}$ progression, $\mathrm{R} / \mathrm{C}$ expression has also been demonstrated in ovarian, ${ }^{13}$ prostate, ${ }^{14}$ pancreatic cancers, ${ }^{15}$ and melanoma. ${ }^{16}$

\section{"Silent Inflammation" in Jawbone: Clinical Features of Fatty-Degenerative Osteonecrosis Jawbone - Definition and Diagnostic Criteria}

Traditional dentistry widely neglects the existence of fatty-degenerative osteonecrosis in the jawbone (FDOJ). Conventional X-ray techniques having limited ability to diagnose location and extension of $\mathrm{FDOJ}^{17}$ probably explains it. To aid the practitioner in diagnosing the debilitating effects of bone marrow softening in FDOJ lesions, a computer-assisted through-transmission alveolar ultrasound (TAU) device has been conceived. ${ }^{18}$ FDOJs are commonly underdiagnosed by dentists due to the difficulty of making a diagnosis when using conventional methods. The softening in FDOJ bone marrow is so distinct that the marrow space can be sucked and spooned out. Hollow cavitations with fatty degenerated adipocytes have undergone dystrophic changes, presenting themselves clinically and macroscopically as fat lumps. Figure 1 illustrates a sample with a fatty modification of the medullary jawbone in the left image. The vast extent of FDOJ lesions is documented in the right image using contrast medium X-ray. To better understand this bone marrow disorder, mainly defined by bone marrow edema and chronic nonsuppurative osteomyelitis, a typical micrograph of FDOJ lesions is presented in Figure 2.

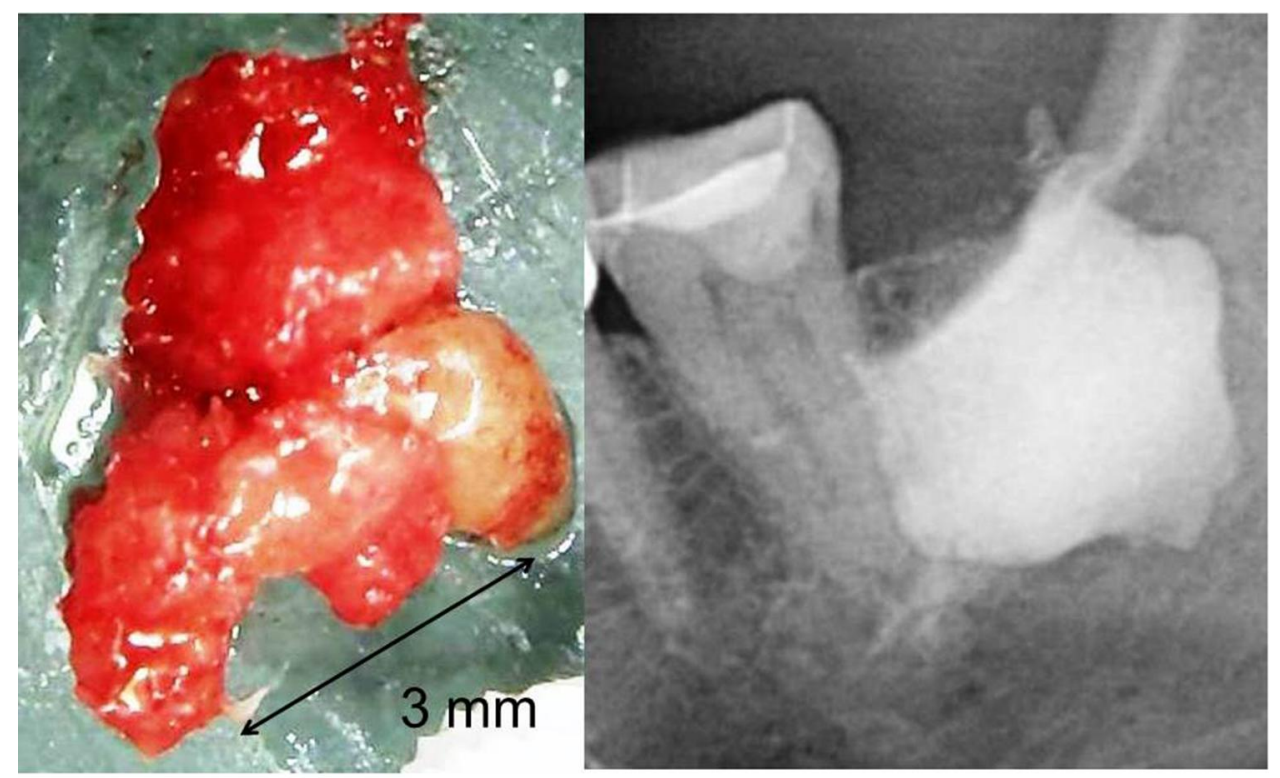

Figure I FDOJ sample of osteolytic degeneration of the bone marrow with fat (left image) and FDOJ cavity filled with contrast medium after curettage (right image) show the extent of the osteolytic process inside the bone marrow. 


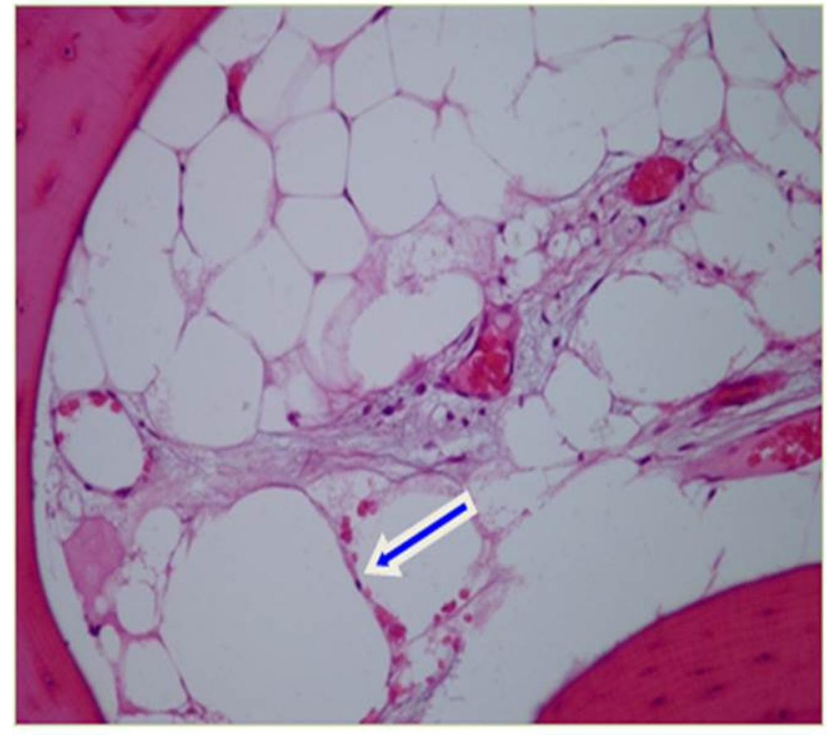

Figure 2 Micrograph of a sample of FDOJ showing osteonecrosis and necrobiotic adipocyte degeneration.

Notes: Bone marrow edema: small region of chronic ischemic damage indicated by loose fibrosis, dilated capillaries, necrotic adipocytes oil cyst (arrow), and mild plasmostasis. Figure reproduced from Lechner J, von Baehr V. RANTES and fibroblast growth factor 2 in jawbone cavitations: triggers for systemic disease? Int J Gen Med. 2013;6:277-290. Creative Commons Attribution - Non Commercial (unported, v3.0) License (https://creativecommons.org/licenses/by-nc/3.0/). ${ }^{19}$

\section{Objectives}

The here presented clinical research aims at clarifying whether the bone-resorbing processes of FDOJ, along with local and systemic functions of any conspicuous accompanying $\mathrm{R} / \mathrm{C}$ overexpression, might contribute to the epistemology of BC in a cohort of $39 \mathrm{BC}$ patients. Thus, this work presents the radiographic, histopathological, immunohistochemical, and mediator-based conditions of the interactions between the well-known role of $\mathrm{R} / \mathrm{C}$ in the propulsion of $\mathrm{BC}$ and disturbed bone remodeling in FDOJ.

\section{Materials and Methods Study Participants}

As the data have been retrieved from patients undergoing standard dental surgery; no inclusion criteria have been set for this study beneath the chronic inflammatory process seen in patients' jawbone. IMD-Berlin (Institute for Medical Diagnostics-Berlin) forensic accredited Institute DIN EN 15,189/DIN EN 17,025 granted the approval. The study was performed in accordance with the Declaration of Helsinki. Signed informed consent was received from all the patients including healthy individuals. The author took FDOJ tissue samples from 39 female patients with BC. Due to their systemic disease, the drug intake of these patients was not disqualifying. Inclusion criteria were the local diagnosis of FDOJ. Medical indication in these patients for FDOJ surgery was provided by orthopantomogram (2D-OPG) and digital volume tomogram (3D-DVT). X-ray diagnostics was supplemented by measuring bone density using trans alveolar ultrasound diagnostics (TAU). ${ }^{17,18}$ The 39 patients included in the $\mathrm{BC}$ collection ranged between 51 and 78 years (mean age, 63.5 years). In a control group of 9 non-BC patients, healthy jawbone samples could be obtained as cores that are produced during standard dental implantation procedures. Inclusion criteria for this healthy control group were: No radiographic abnormalities in 2D and 3D OPG-DVT; neutral TAU measurements of bone density in the implantation area and absence of clinically manifest tumor. The use of bisphosphonate drugs was a key exclusion criterion for both groups. The 9 patients in the non-BC/non-FDOJ control group showed $155.9 \mathrm{pg} / \mathrm{mL}$ for $\mathrm{R} / \mathrm{C}$ in healthy medullary maxillary bone. ${ }^{19,21}$ The demographic data were as follows: mean age, 49.8 years (range: $33-72$ years).

\section{FDOJ Samples for RANTES/CCL5 Expression via Multiplex Examination}

FDOJ samples obtained from lower and upper jaws were analyzed via R/C multiplex [IMD-Berlin Nicolaistrasse 22, 12,247 Berlin, Germany] expression to clarify the possible link seen between the fatty cells and their expressed mediators. Patients undergoing surgery at the author's clinic and with a suspicion of chronic inflammation in the jawbone provided the clinical material. Previously published studies ${ }^{19}$ have highlighted the up to 35-fold overexpression of R/C chemokine in FDOJ areas; this proinflammatory chemokine being the only one that is overexpressed in these areas, we focused on our investigation solely on this one. The expression of CCL5 has been measured in 48 jaw bone samples of two different tissue types: 39 samples were from FDOJs extracted from BC patients, and 9 samples were taken out of healthy bone from non-BC patients. The BC cohort samples were typically obtained in wisdom (area \#8) and retromolar (area \#9) tooth areas. FDOJ samples (clinical example of this morphology shown in Figure 1) were extracted to a volume of up to $0.5 \mathrm{~cm}^{3}$ and stored in a sterile collection tube (Starstedt Micro-Tube Ref. 72.692.005) right after extraction. Tubes were sealed and kept at $-20^{\circ} \mathrm{C}$ until shipment to the laboratory. Tissue samples are mechanically processed upon arrival at the laboratory, taken up in 
$200 \mu \mathrm{L}$ of protease buffer (Complete Mini Protease Inhibitor Cocktail, Roche, D), and homogenized. The homogenate was centrifuged for 15 minutes at 13,400 rpm; the supernatant was removed and centrifuged for an additional 25 minutes at 13,400 rpm. Millipore Human Cytokine/Chemokine Panel I (MPXHCYTO-60K, Millipore $\mathrm{GmbH}$, Schwalbach, D) is used, according to the manufacturer's protocol, to determine $\mathrm{R} / \mathrm{C}$ concentration from the supernatant of the tissue homogenate. Luminex $200^{\mathrm{TM}}$ combined with $\mathrm{xPotent}(\mathrm{C}$ software (Luminex, Austin, TX, USA) is used to perform the results readout.

\section{Laboratory Analysis of RANTES/CCL5 in Serum}

Serum values were collected from all participants as a parameter to evaluate the effect of jawbone surgery in FDOJ areas. Serum R/C (S-R/C) levels were measured twice: first (T0) before FDOJ surgery and second 4 weeks (T1) after FDOJ surgery. Serum was taken intravenously in all patients using $7.5 \mathrm{~mL}$ collection tube with heparin (Sarstedt). The same procedure was done four weeks after FDOJ surgery. Measurement of S-R/C in serum was performed as described under point 3.2. For measurement of $\mathrm{R} / \mathrm{C}$ in serum, a predilution 1:100 of the samples in sample buffer according to the manufacturer's instructions was performed. Examining Institute for Medical Diagnostics, Nikolaistr. 22, D-12,247 Berlin performed the analysis (inspected by DAKKS [Deutsche Akkreditierungsstelle GmbH; accredited to DIN EN ISO/IEC 17,025:2005 and DIN EN ISO 15,189:2007])

\section{Histological Description of the Fatty-Degenerative Change in the Jawbone}

Every FDOJ bone sample was examined under light microscopy with standardized Hemalaun and Eosin stain.

\section{Immunohistochemistry of RANTES/CCL5 Expression in FDOJ}

After oven drying, dewaxing, and peroxidase blocking ( $1 \%$ $\left.\mathrm{H}_{2} \mathrm{O}_{2}\right), 5 \mu \mathrm{m}$ sections of poly-L-lysine-coated slides were used for immunohistochemistry analysis. Authors replaced primary antisera with normal rabbit serum to test immunostaining specificity. No additional pre-treatment procedures for antigen retrieval were done. The immunoreactions were performed using antibody and staining protocol as follows: AntiRANTES/CCL5 (polyclonal; Abcam; dilution 1:500; retrieval CC1 68'; incubation, Benchmark Ultra; chromogen, Ultra
View Red). Immunoreaction was considered when visible red precipitation was observed. As shown in Immunohistochemistry studies, R/C-positive cells are very rarely, if ever, seen in normal adult tissues. In contrast, in inflamed areas, the $\mathrm{R} / \mathrm{C}$ expression is significantly increased. Further, R/C-positive cells are often highly expressed in some tumors, fetal tissues, and megakaryocytes. A broader expression of $\mathrm{R} / \mathrm{C}$ than previously thought seems to exist in several physiological processes. ${ }^{20}$ Selected polyclonal anti-RANTES antibodies are here used for immunohistological staining of FDOJ tissue selections in two BC patients [Schulz, T. Institut für Pathologie, Klinikum Bayreuth $\mathrm{GmbH}$, Preuschwitzer Str. 101, 95,445 Bayreuth. Germany]. To our knowledge, we are the first to visualize and quantify $\mathrm{R} / \mathrm{C}$ overexpression in the jawbone using immunohistochemistry. ${ }^{21}$ This is shown in Immunohistochemistry and Staining of RANTES/CCL5 Expression in the Jawbone in Two Breast Cancer Patients by two clinical cases of FDOJ from $\mathrm{BC}$ patients.

\section{Immunohistochemistry of RANTES/CCL5 Expression in Breast Cancer}

To compare the intensity of $\mathrm{R} / \mathrm{C}$ expression in $\mathrm{BC}$-associated adipocytes with the staining intensity of areas affected by FDOJ, we stained two histological $\mathrm{BC}$ preparations for immunohistochemical analysis. This is shown in Immunohistochemistry and Staining of Breast Cancer Preparations by two clinical cases with BC.

\section{Statistical Analyses}

Descriptive statistical analyses of the measurements of the FDOJ and control groups were performed. Assessment of whether non-parametric or parametric testing would be more appropriate for the analysis was performed through analysis of data distribution, means, and medians. Student's $t$-test or Spearman's Rho was used to determine the differences between cohorts. A P value of $<0.05$ was set for significance.

\section{Results and Case Studies Multiplex Analysis of 39 FDOJ Samples in Breast Cancer Cases -RANTES/CCL5 Expression When Compared to the Healthy Jawbone}

The multiplex analysis from the BC-FDOJ cohort samples $(n=39)$ showed remarkable overexpression (Figure 3): R/C showed a median of $3971 \mathrm{pg} / \mathrm{mL}(\mathrm{SD} \pm 2836)$. Nine healthy 


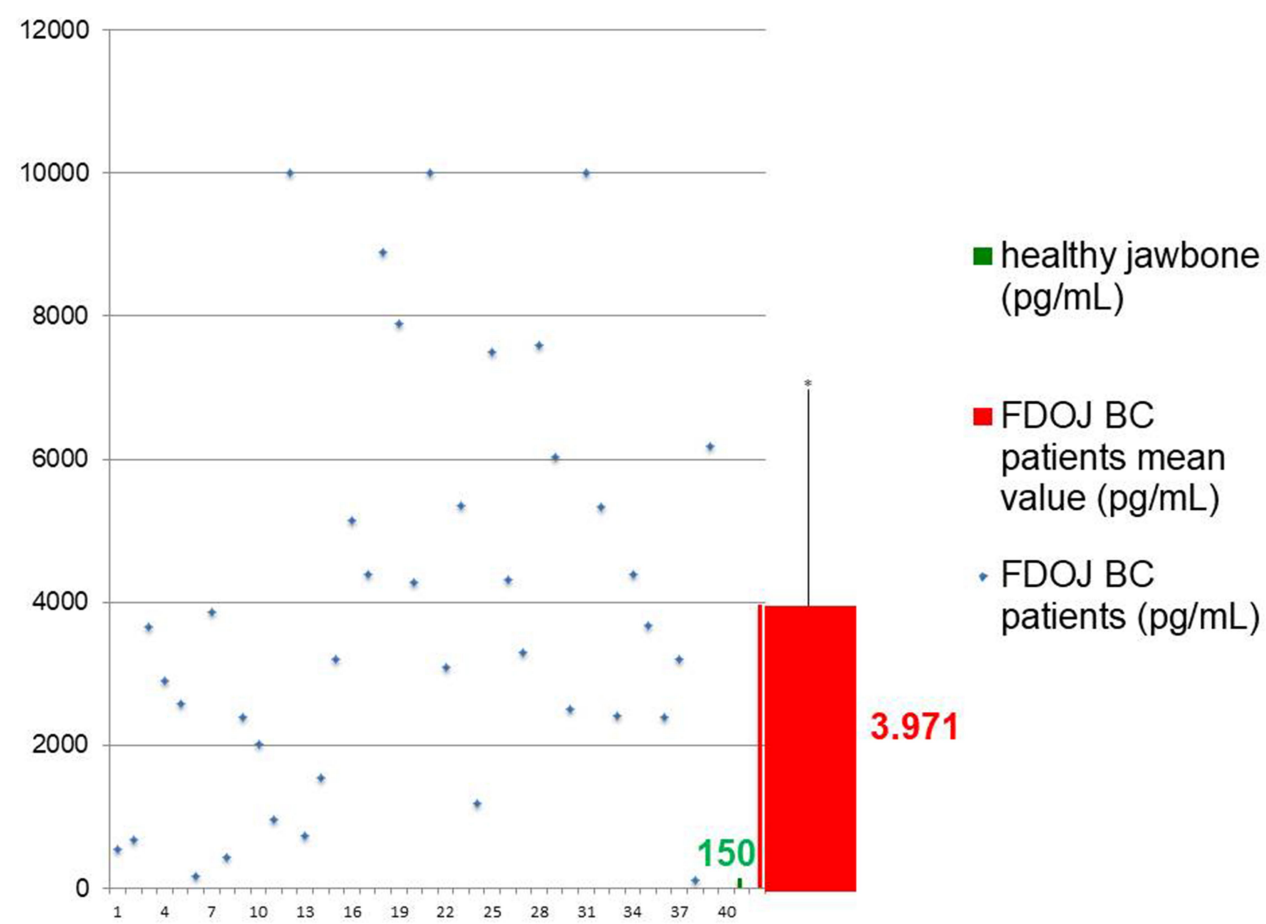

Figure 3 R/C expression distribution of 39 FDOJ samples from BC patients compared to healthy jawbone samples ( $n=9)$.

Notes: Blue spots show individual R/C expression; green bar shows R/C expression in the healthy jawbone (I55.9 $\mathrm{pg} / \mathrm{mL})$; red bar shows the median value of R/C expression in $39 \mathrm{BC}$ samples $(3.971 \mathrm{pg} / \mathrm{mL})$.

jaw bone samples showed an R/C expression of $155.9 \mathrm{pg} /$ $\mathrm{mL}(\mathrm{SD} \pm 128)$ in the multiplex analysis. Comparative values from the literature were not available. Striking is the strong dispersion of FDOJ-R/C values in the $\mathrm{BC}$ cohort; nevertheless, all are clearly above the median of the control cohort of $155.9 \mathrm{pg} / \mathrm{mL}$. Three samples achieve an $\mathrm{R} / \mathrm{C}$ expression of $>10,000 \mathrm{pg} / \mathrm{mL}$, which exceeds the maximum measurement range of the current multiplex analyzer. Impressive is the approximately 26-fold overexpression of chemokine $\mathrm{R} / \mathrm{C}$ from FDOJ samples of the $39 \mathrm{BC}$ patients. ( $\mathrm{R} / \mathrm{C}$-values $155.9 \mathrm{mg} / \mathrm{mL}$ of healthy jawbone were set to $150 \mathrm{pg} / \mathrm{mL}$.)

\section{Clinical Cases of 2 Breast Cancer Patients - Comparison of X-Ray Diagnostics, R/C Expression, and Light Microscopy}

All FDOJ cases share common features with inconspicuous, two-dimensional (2D) X-ray diagnostics. In contrast, they exhibited a positive diagnosis for FDOJ based on Trans Alveolar Ultrasonography (TAU) and demonstrated noticeable softening of fatty-degenerative changes in medullary morphology. TAU represents a radiation-free measurement of bone density, indicating highly significant jawbone marrow defects and osteolysis.

\section{Case Study \#I}

History: 2012 breast cancer (left side); 2015 recurrent breast cancer (left side). Histological diagnosis and assessment area 38/39 (Figure 4): Adipose tissue with caliber fluctuations of adipocytes with only discrete myxoid swelling; small lymph cell aggregates; no relevant inflammation. Figure 5 displays FDOJ sample taken from area 38/ 39 and multiplex analysis of $\mathrm{R} / \mathrm{C}$ overexpression.

\section{Case Study \#2}

History: 2016 recurrent Breast cancer (left side), first surgery 2015. Histological diagnosis and assessment area 17/18: Marrow spaces with fatty tissue, increasingly proliferated capillaries in peripheral areas, low interstitial fibrosis, fibrillar degeneration. No inflammatory cells. Figure 6 displays inconspicuous area $17 / 18$ in X-ray, FDOJ sample taken from area 17/18 and multiplex analysis of $\mathrm{R} / \mathrm{C}$ overexpression in area 17/18.

\section{Immunohistochemistry and Staining of RANTES/CCL5 Expression in the Jawbone in Two Breast Cancer Patients}

Since our osteoimmunological investigation aims at examining the systemic interactions of $\mathrm{R} / \mathrm{C}$ overexpression in 

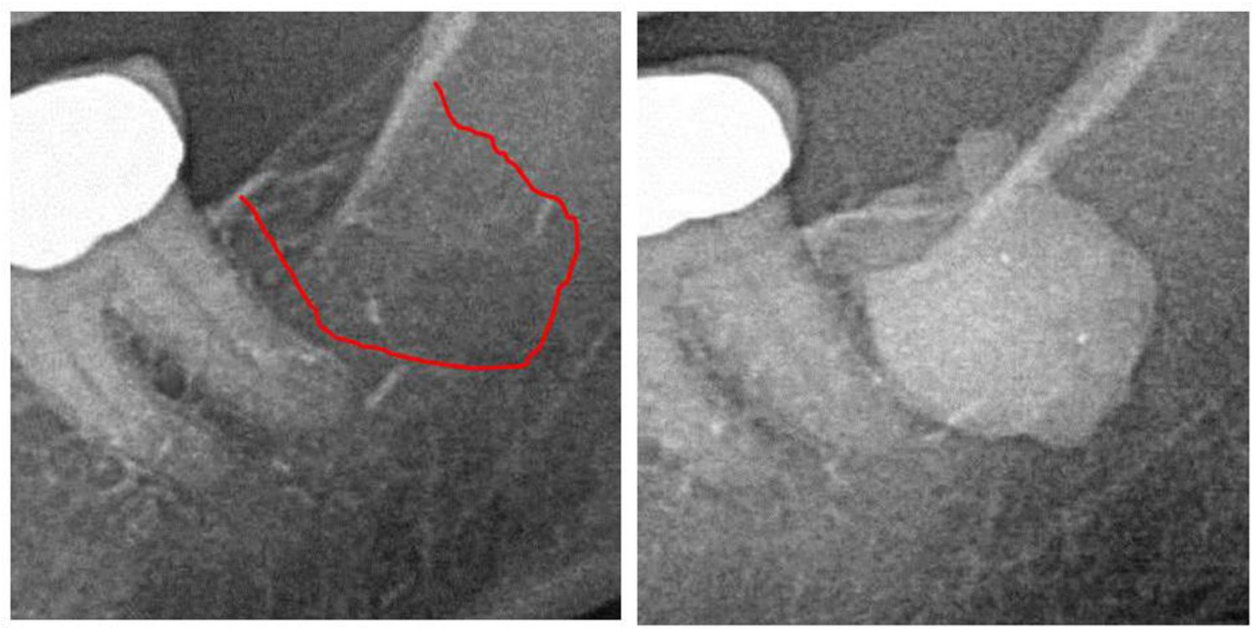

Figure 4 Left panel: 2D X-ray diagnostics of area 38. Right panel: Documentation of the expanse of FDOJ in retromolar area 38/39 using a contrast agent after FDOJ surgery.
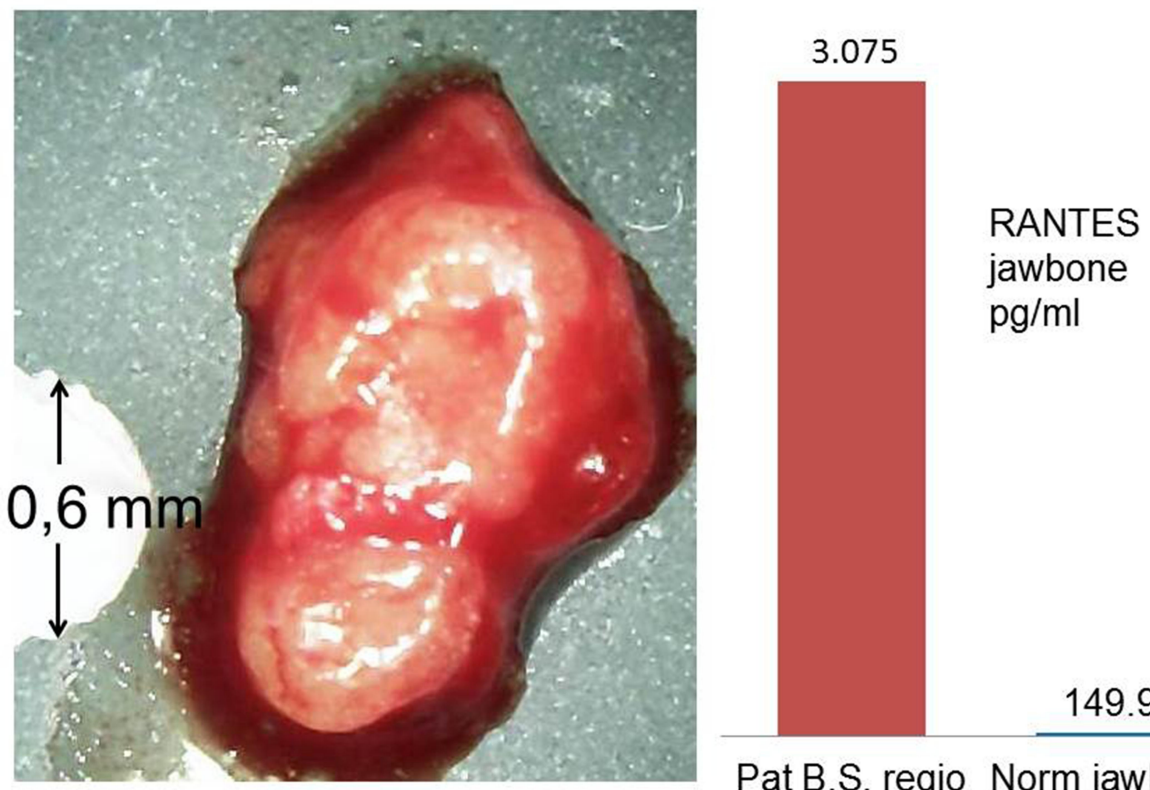

149.9

Pat B.S. regio Norm jawbone $38 / 39 \quad(n=19)$

Figure 5 Left image: Morphology of FDOJ sample taken from area 38/39; spongy bone is completely replaced by soft lump of fat. Head of a ceramic drill with $0.6 \mathrm{~mm}$ diameter shows the extent of FDOJ in the bone. Right image: R/C expression (Multiplex) of this FDOJ sample is $3.075 \mathrm{pg} / \mathrm{mL}$ (norm $=155.9 \mathrm{pg} / \mathrm{mL}$ ).

areas affected by FDOJ, we performed an immunohistochemical analysis of $\mathrm{R} / \mathrm{C}$ expression in two FDOJ tissues originating from $\mathrm{BC}$ patients in figures 7 and 8 .

\section{Case Study \#I: 5I Years Old Female} Clinical Diagnosis and Symptoms: Breast Cancer

Histological diagnosis and assessment: Marrow tissue extracted from jawbone area 18/19 with exclusively fatty marrow are presented in sections with necrobiotic changes, small and loose fibrosis, and scant inflammatory round-cell infiltrates (Figure 7). These findings are suggestive of FDOJ.

\section{Case Study \#2: 63 Years Old Female} Clinical Diagnosis and Symptoms: Breast Cancer

Histological diagnosis and assessment: Jawbone/medullary tissue area 18/19 with normal blood-forming marrow, which is also associated with veritable cancellous bone particles. In particular, the material present here indicates 

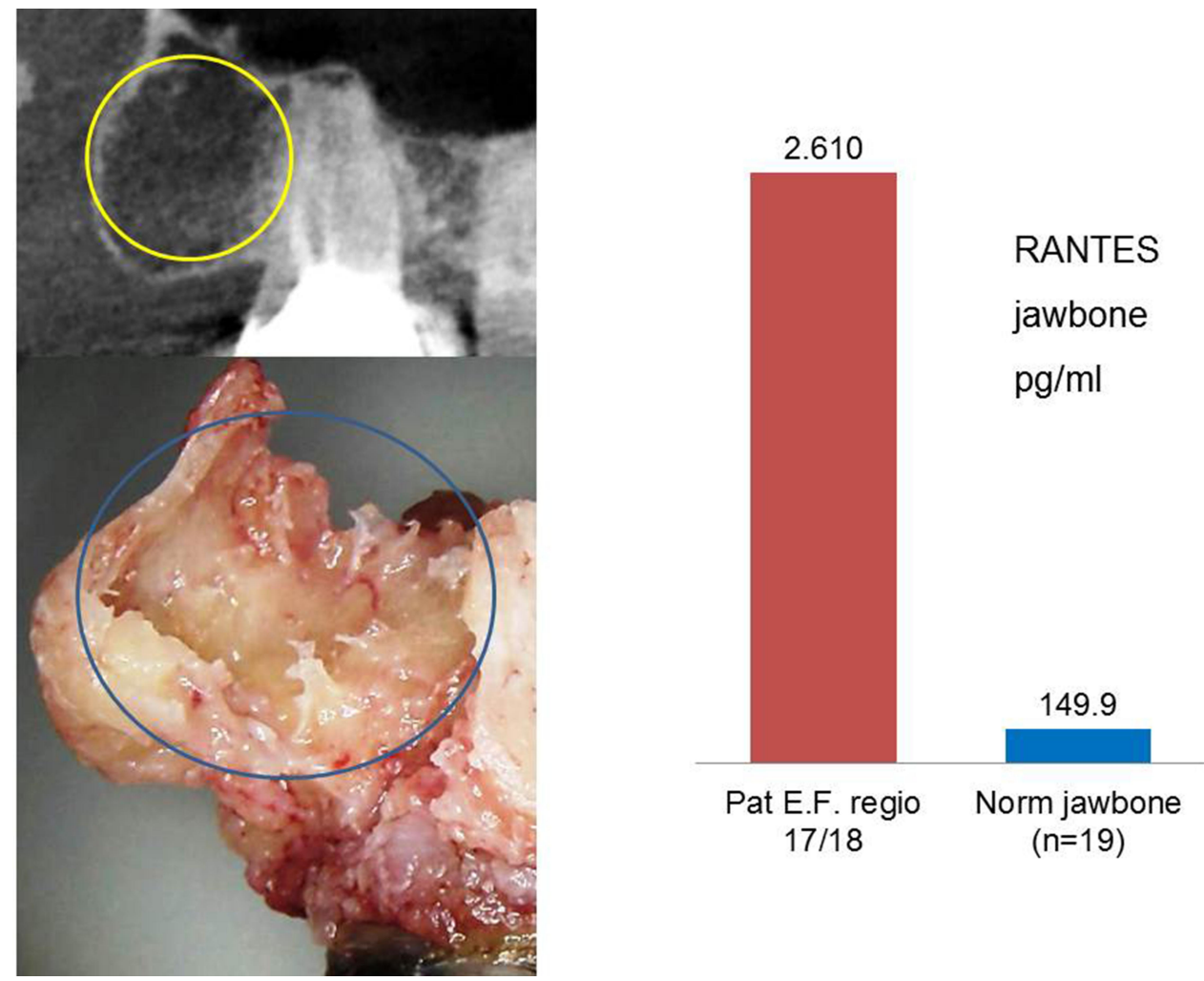

Figure 6 Left upper image: 2D X-ray of area 17/I8. Left lower image: Morphology of FDOJ in area 17/I8; yellowish fat fills the medullary space instead of trabecular bone. Right image: R/C expression (Multiplex) of $2.610 \mathrm{pg} / \mathrm{mL}$ (norm $=155.9 \mathrm{pg} / \mathrm{mL}$ ).

no degenerative bone marrow changes (Figure 8). There is no indication of malignancy.

\section{Immunohistochemistry and Staining of Breast Cancer Preparations}

Numerous studies in the literature have shown how R/C contributes to the development and progression of BC. ${ }^{22-24}$ To compare, we also performed an immunohistochemical analysis of $\mathrm{R} / \mathrm{C}$ expression in $\mathrm{BC}$ tissues with the same antibodies as those in areas affected by FDOJ. The tumor cell clusters were stained, although relatively weakly. Between tumor cells, single cells with intense staining were evident. These cells are not mature adipocytes; instead, there are many other cell types present in adipose tissue (see The Role of Adipocytes and RANTES/CCL5 in Tumor Growth and Proliferation), including stem cells, fibroblasts, endothelial cells, macrophages, and adipocyte progenitor cells (pre-adipocytes). Thus, many cells are strongly stained in fatty, tissue-rich connective tissues surrounding the epithelial tumor cells, indicative of R/C-positive cells. Figures 9 and 10 show the results of $\mathrm{BC}$ staining. ${ }^{2}$

\section{RANTES/CCL5 in FDOJ Samples versus Serum Samples}

As it is the goal of FDOJ surgery to remove the fatty tissues in FDOJ areas, hence removing the source of $\mathrm{R} / \mathrm{C}$ overexpression, the authors checked the $\mathrm{R} / \mathrm{C}$ levels in serum $(\mathrm{S}-\mathrm{R} / \mathrm{C})$. In five $\mathrm{BC}$ patients, multiple measurements of $R / C$ in serum after two $(n=4)$ or three $(n=1)$ FDOJ operations were always performed at intervals of at least 4 and a maximum of 6 weeks. The result is shown in Table 1 as a percentage of the Reduction of S-R/C level in five BC patients after surgery. Again, there is a statically relevant correlation $(\mathrm{P}$ value $=0.0241)$ (Figure 11). In summary, we found a positive impact of FDOJ surgery on S-R/C level.

To assess the systemic efficacy of the local surgical procedure in the jawbone, we measured $\mathrm{R} / \mathrm{C}$ expression in serum samples of $16 \mathrm{BC}$ patients $>12$ months after FDOJ surgery. The calculation of Spearman correlation coefficient between $\mathrm{R} / \mathrm{C}$ in FDOJ and $\mathrm{R} / \mathrm{C}$ in serum gives - due to the small number of cases - a weak positive correlation which is not significant according to the p-value of 0.259 (Figure 12). 

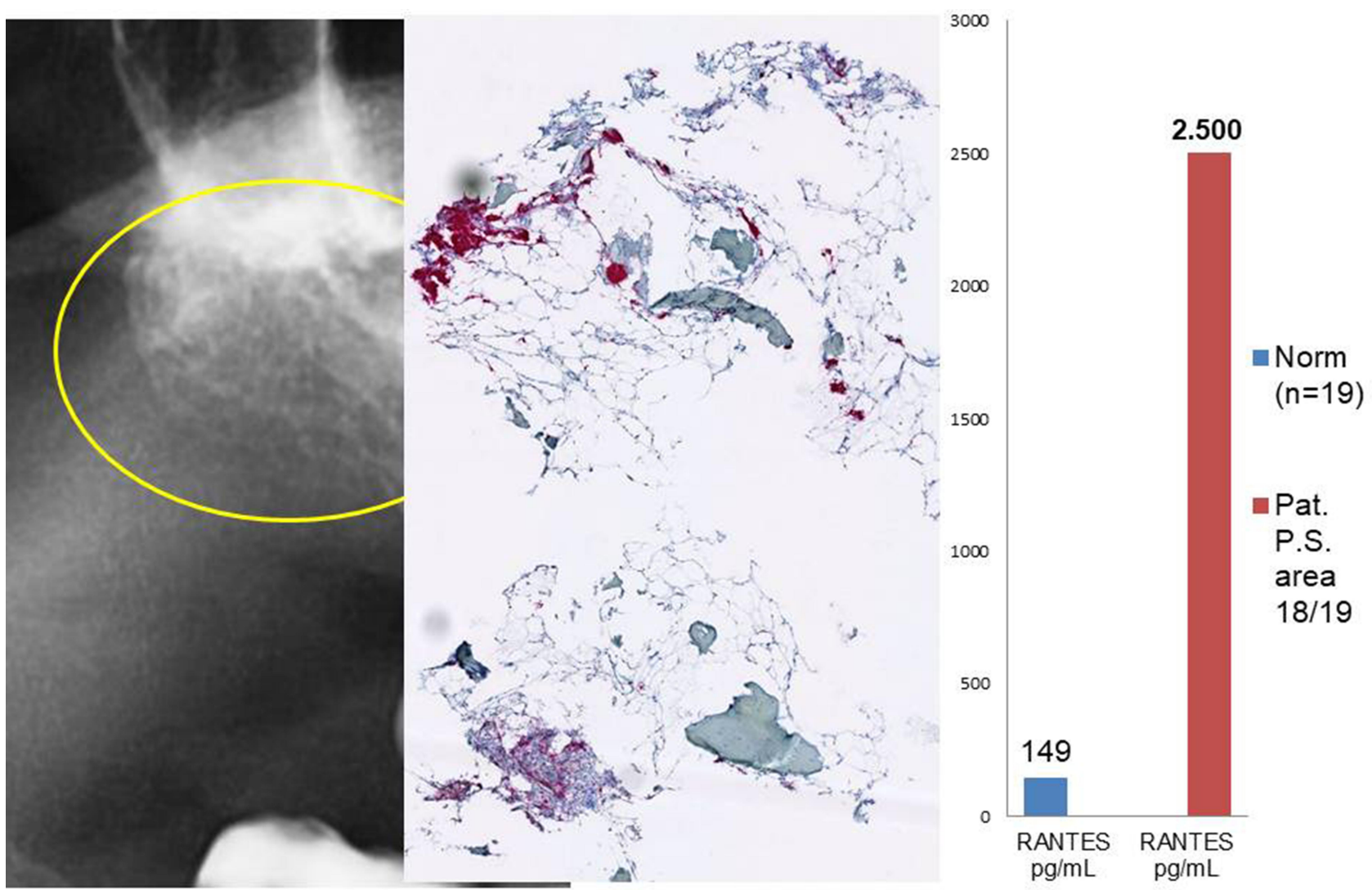

Figure 7 Left panel: 2D X-ray of area 18/19 showing - II8 HU bone density. Middle panel: Immunohistochemistry with strong red staining of adipocytogenic R/C overexpression. Right panel: R/C expression (Multiplex) of $2.500 \mathrm{pg} / \mathrm{mL}$ (norm $=155.9 \mathrm{pg} / \mathrm{mL}$ ).

\section{Discussion}

Authors describe the possible pathologic function of $\mathrm{R} / \mathrm{C}$ overexpression in the jawbone and their possible relevance as tumorigenic agents in $\mathrm{BC}$ cases based on in vivo pharmacological data and identify a hitherto neglected area of fat beyond obesity: Fatty-degenerative altered areas in jawbone medullary space. These areas are to be found in mandibular and maxillary edentulous areas of former tooth extractions or wisdom tooth surgeries. Interestingly, the pathohistological findings in each case presented did not show any inflammation or inflammatory cells. The authors' hypothesis guides the focus from an inflammatory theory of tumorigenesis to a derailed signaling pathways aspect, primarily through $\mathrm{R} / \mathrm{C}$ overexpression in fatty-degenerated areas of jawbone marrow. Numerous publications on adipocytes that function as "cancer-associated adipocytes" by means of adipocytegenerated $\mathrm{R} / \mathrm{C}$ and their contribution to tumor regeneration and growth are found in the literature. ${ }^{22-24}$ Further, $\mathrm{R} / \mathrm{C}$ expression from hematopoietic stem cells (HSCs) correlates with advanced human $\mathrm{BC} .{ }^{25} \mathrm{R} / \mathrm{C}$ expression may indicate a continuous, yet undetectable, malignant process. $^{26}$ In recent years, mesenchymal stem cells (MSCs) derived $\mathrm{R} / \mathrm{C}$ has been shown to contribute to the motility, invasion, and metastasis of cancer cells. ${ }^{27,28}$ Given this context, it seems worthwhile and necessary while further investigating patients affected by immune system disorders and tumors - to present the multilayered picture of a possible association between clinically inconspicuous findings in the preoperative $\mathrm{X}$-ray, intraoperative osteolysis of the jawbone, and concomitant R/C overexpression in areas affected by FDOJ and to clarify contradictory histological findings. Interestingly, a search for "Breast cancer CCL5" in PubMed shows 190 scientific papers published since 1997. In contrast, "Jawbone CCL5" brings up only 13 results, all from the corresponding author and coauthors. This proves the widespread medical knowledge on the importance of $\mathrm{R} / \mathrm{C}$ in breast cancer and possible trigger between FDOJ and BC. Vice versa, it highlights the ignorance of $\mathrm{R} / \mathrm{C}$ in dentistry. 


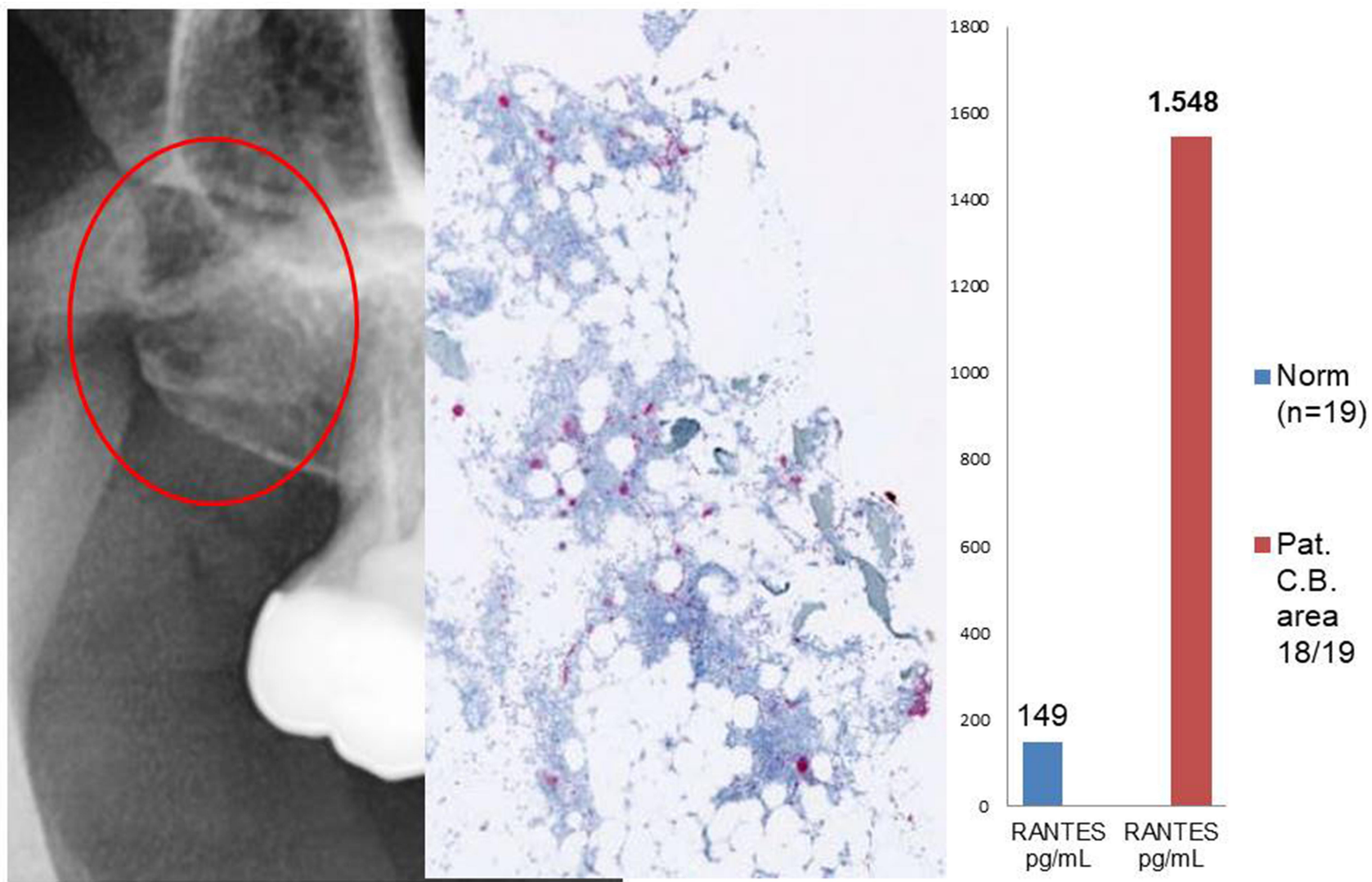

Figure 8 Left panel: 2D X-ray of area 18/19. Middle panel: Immunohistochemistry without signs of R/C overexpression. Right panel: atypical R/C expression (Multiplex) of $1.548 \mathrm{pg} / \mathrm{mL}$ (norm $=155.9 \mathrm{pg} / \mathrm{mL})$.

A short review on the role of $\mathrm{R} / \mathrm{C}$ in the pathogenesis of $\mathrm{BC}$ and the possible link to FDOJ is proposed.

\section{Adipose Tissue and RANTES/CCL5 in Obesity, in Breast Cancer, and in FDOJ}

In obesity, adipocytes are profoundly impacted, not only in size and number but also as secretory bodies. Hence, studying the effect of fat cells on disease progression is of major interest in medicine, especially for the treatment of obese patients. ${ }^{32}$ While the mechanism linking obesity and cancer development has not been demonstrated to date, overweight breast cancer patients often suffer more aggressive tumors at diagnosis, faster disease, and higher mortality rate. It has been shown that Adipose tissues are mediators of chronic inflammation ${ }^{30,31}$ and induce a shift in secreted cytokines from anti-inflammatory to proinflammatory/proangiogenic profile, linking $\mathrm{R} / \mathrm{C}$ to adipocyte tumorigenesis. ${ }^{29}$

$\mathrm{R} / \mathrm{C}$ levels were measured by Niwa et al in primary malignancies and were found to be increased in all breast tumor samples. $\mathrm{R} / \mathrm{C}$ level of $1.032 \pm 120 \mathrm{pg} / \mathrm{mg}$ in $\mathrm{BC}$ tissues was reported. ${ }^{23}$ Comparable high levels (797.6 $\pm 3.96 \mathrm{pg} / \mathrm{mL}$ ) were found by Eichbaum and $\mathrm{al}^{33} \mathrm{R} / \mathrm{C}$ expression has been shown to be significantly higher ( $\mathrm{p}$ : $0.023)$ in adipose tissue of obese $(1.750 \pm 120 \mathrm{pg} / \mathrm{mL}$; $\mathrm{n}=40)$ versus lean people $(1.240 \pm 180 \mathrm{pg} / \mathrm{mL} ; \mathrm{n}=17) .{ }^{35}$

Higher R/C levels in obese people's adipose tissue, ${ }^{34}$ along with a raise of the same chemokine in presently observed BC connective adipose tissue (Figure 13) and $\mathrm{BC}$ tissue, ${ }^{32,33}$ lead the authors to the role that $\mathrm{R} / \mathrm{C}$ FDOJ could have on breast cancer development, and the listing of FDOJ as therapeutic objective as well as in pathogenic considerations.

\section{The Role of Adipocytes and RANTES/ CCL5 in Tumor Growth and Proliferation}

The discussion on BC patients presented in Case Study \#1: 51 Years Old Female and Case Study \#2: 63 Years Old Female established that adipocytes in FDOJ may constitute part of the pathogenetic linkage between cytokine and chemokine expression in other adipose tissues. $\mathrm{BC}$ aggressiveness is promoted by adipocytes secreted proinflammatory 


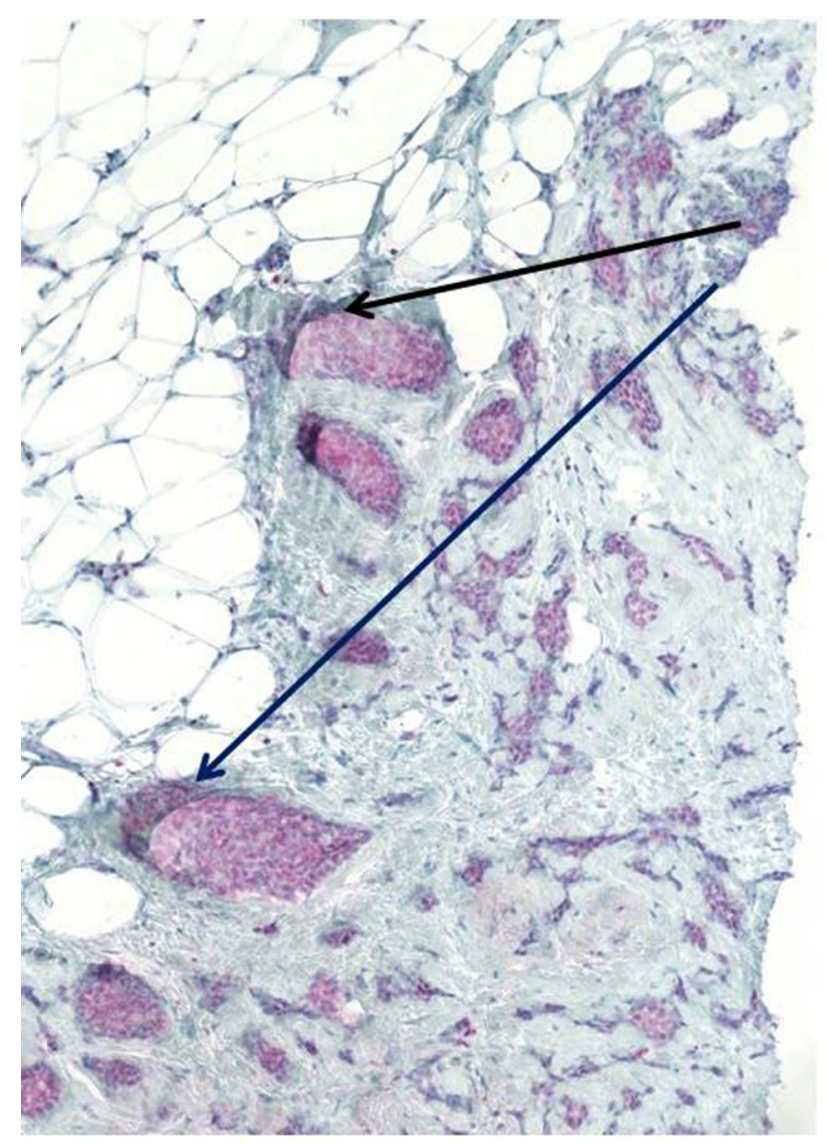

Figure 9 Duct-invasive breast carcinoma with R/C-positive tumor cell nests (arrows). The staining is not as strong as in the FDOJ samples.

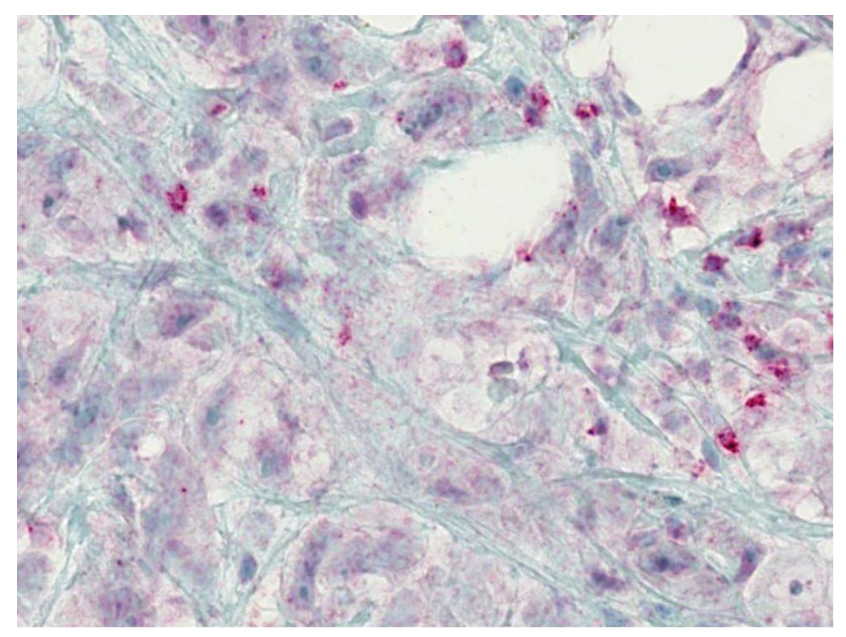

Figure 10 Breast cancer and associated connective adipose tissue. There are also distinct R/C-stained cells, while the breast cancer epithelial tracts show only mild-to -moderate, non-specific background staining.

cytokines, such as $\mathrm{R} / \mathrm{C}$, which has been linked to aggressive $\mathrm{BC}^{23}$ in more than $58 \%$ of $\mathrm{BC}$ patients. ${ }^{12}$ While many scientific studies have shown the connection between fat cells and tumor growth, ${ }^{35}$ by the author the
Table I Reduction of R/C in Serum After FDOJ Surgery in Five BC Patients

\begin{tabular}{|l|c|c|c|c|c|}
\hline $\begin{array}{l}\text { Patient } \\
\text { Ref. }\end{array}$ & $\begin{array}{c}\text { CCL5 } \\
\text { Serum } \\
\text { Value I } \\
(\mathbf{n g} / \mathbf{m L})\end{array}$ & $\begin{array}{c}\text { CCL5 } \\
\text { Serum } \\
\text { Value 2 } \\
(\mathbf{n g} / \mathbf{m L})\end{array}$ & $\begin{array}{c}\text { CCL5 } \\
\text { Serum } \\
\text { Value 3 } \\
(\mathbf{n g} / \mathbf{m L})\end{array}$ & $\begin{array}{c}\text { Months } \\
\text { Between } \\
\text { Surgeries }\end{array}$ & $\begin{array}{c}\text { CCL5 } \\
\text { Serum } \\
\text { Red. } \\
\text { (\%) }\end{array}$ \\
\hline $\mathrm{I}$ & 59.2 & 30.8 & - & 4 & -48 \\
2 & 120.2 & 87.5 & - & 6 & -27.2 \\
3 & 79 & 33 & 61.7 & 12 & -58.2 \\
4 & 33 & 32.7 & - & 0.8 & -0.9 \\
5 & 76.2 & 25.3 & - & 1 & -66.8 \\
\hline
\end{tabular}

overexpression of $\mathrm{R} / \mathrm{C}$ in $\mathrm{BC}$ patients in vivo fat cells was detected through multiplex examinations and thus were able to derive a hypothetical interaction between local sources of FDOJ and organ-specific adipocyte characteristics. ${ }^{36}$ Our assumption is based on the fact that both the FDOJ bone marrow and diseased mammary gland have a pathologically altered, adipocyte-rich environment. The level of agreement between $\mathrm{R} / \mathrm{C}$ expression in the staining of FDOJ and $\mathrm{BC}$ preparations described in Clinical Cases of 2 Breast Cancer Patients - Comparison of X-Ray Diagnostics, R/C Expression, and Light Microscopy-RANTES/CCL5 in FDOJ Samples versus Serum Samplesreveals these potential relationships. R/C was not found to be extremely overexpressed at area 18/19 in case 10 with a density of $548 \mathrm{pg} /$ $\mathrm{mL}$; however, this does not refute our hypothesis. Instead, this finding represents the final phase of more vital, decades-long $\mathrm{R} / \mathrm{C}$ activity on tumor-associated adipocytes in $\mathrm{BC}$.

Under adipogenic conditions, bone marrow-derived monocytic progenitor cells differentiated into adipocytes contributing to the tumor microenvironment, $\mathrm{BC}$ growth and metastasis, ${ }^{38-40}$ often linked to $\mathrm{R} / \mathrm{C}^{29}$ being currently seen as a potential target for treatment and/or prevention of $\mathrm{BC}$ metastases. ${ }^{41}$ New evidence indicates that adipocytes, referred to as "cancer-associated adipocytes" (CAA) ${ }^{35}$ leaking lipids in the form of free fatty acids are important to cancer cells for their energy production, ${ }^{41,42}$ while chemokines - such as $\mathrm{R} / \mathrm{C}$ - and adipokines affect tumor growth, metastasis, and chemoresistance in a variety of cancers. ${ }^{37}$ CAAs are able to provide increased levels of proinflammatory cytokines ${ }^{38}$ such as $\mathrm{R} / \mathrm{C}$ which significantly increases the risk of disease progression ${ }^{23,42}$ and poor prognosis, ${ }^{24}$ proteases, ${ }^{39}$ and extracellular matrix components ${ }^{40}$ for cancer cells, thereby accelerating tumor progression. CAAs may also accumulate oil droplets that contain triglycerides (see Background: Morphology of 


\section{$R / C$ in serum (breast cancer patients)}

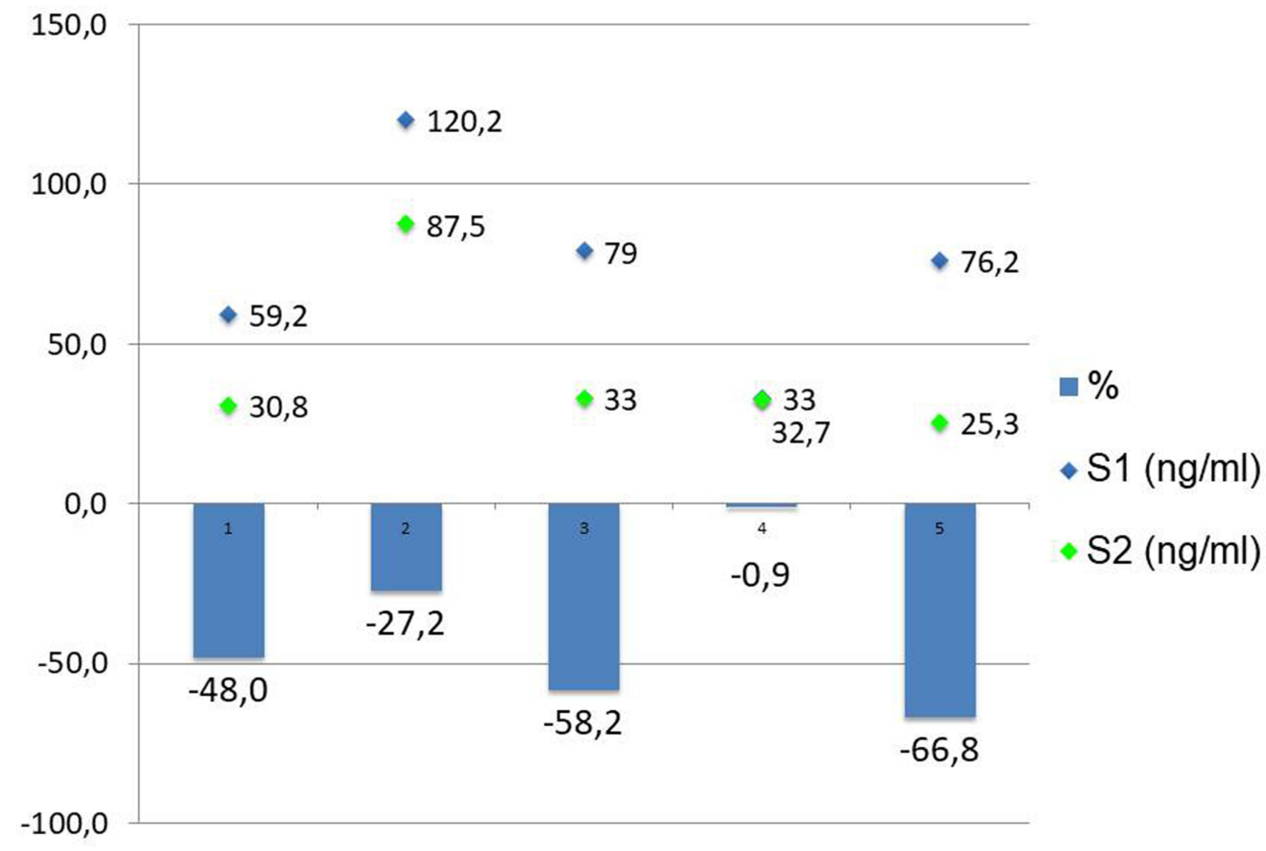

Figure I I Comparison of pre-FDOJ surgery R/C serum levels with serum levels post-FDOJ surgery in 5 BC patients.

$\mathrm{pg} / \mathrm{mL}$

Breast Cancer patients

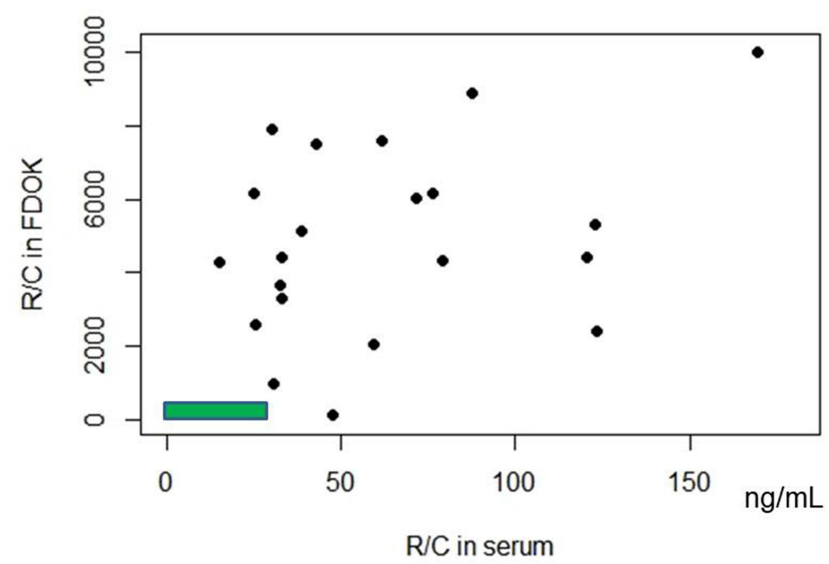

Figure 12 Distribution of R/C in FDOJ $(\mathrm{pg} / \mathrm{mL})$ and in serum $(\mathrm{ng} / \mathrm{mL})$ in 16 breast cancer patients. Green area shows range of FDOJ R/C expression correlated to R/ $C$ expression in serum in healthy female cohort.

FDOJ). Tumor-derived $\mathrm{R} / \mathrm{C}$ is detected in many clinical samples of breast cancer; higher plasma $\mathrm{R} / \mathrm{C}$ levels are found in patients suffering from advanced malignancy when compared to those under remission.

Newly discovered adipocyte populations are derived from bone marrow-derived circulating progenitor cells. $^{43-45}$ The contribution of HSC-derived adipocytes (HSC-Ad) on tumor progression may be established by secreting HSC-Ad growth factors and adipokines, which include $\mathrm{R} / \mathrm{C}$, that regulate the migration of cancer cells differently. ${ }^{35}$ Consistent with this finding, the $\mathrm{R} / \mathrm{C}$ overexpression we observed in FDOJ areas in affected $\mathrm{BC}$ patients provides the same picture. ${ }^{46}$ Thus, HSC-Ads are likely to play a crucial role in lipid metabolism progression and may also pose a greater risk in obesity-related gynecological cancer in women. ${ }^{47}$

The objective of reducing $\mathrm{R} / \mathrm{C}$ signaling thus follows the same objective as FDOJ remediation. Specifically, from the over 200 peptide growth factors and cytokines that were tested, the secretion of interleukin IL-6, IL-8, interferon gamma-induced protein (IP)-10, CCL2, and R/C demonstrated a synergistic increase in breast adipocyte cocultures. Immature adipocytes are elevated and act as proinflammatory mediators in adipose tissue. They express higher levels of basal cytokines, and these are increased via co-culture to significantly higher levels than in cancer cells. $^{49}$ Increased IL-8, IL-6, CCL2, and $\mathrm{R} / \mathrm{C}$ in primary $\mathrm{BC}$ are each correlated with an advanced stage, poor differentiation, and poor treatment outcomes, while elevated circulating cytokines are associated with a poorer prognosis. $^{22,50}$ We recently outlined the relationship between these factors and the development and progression of FDOJ. ${ }^{51}$

Three groups of adipocytes contribute to tumor development through different signaling pathways: 


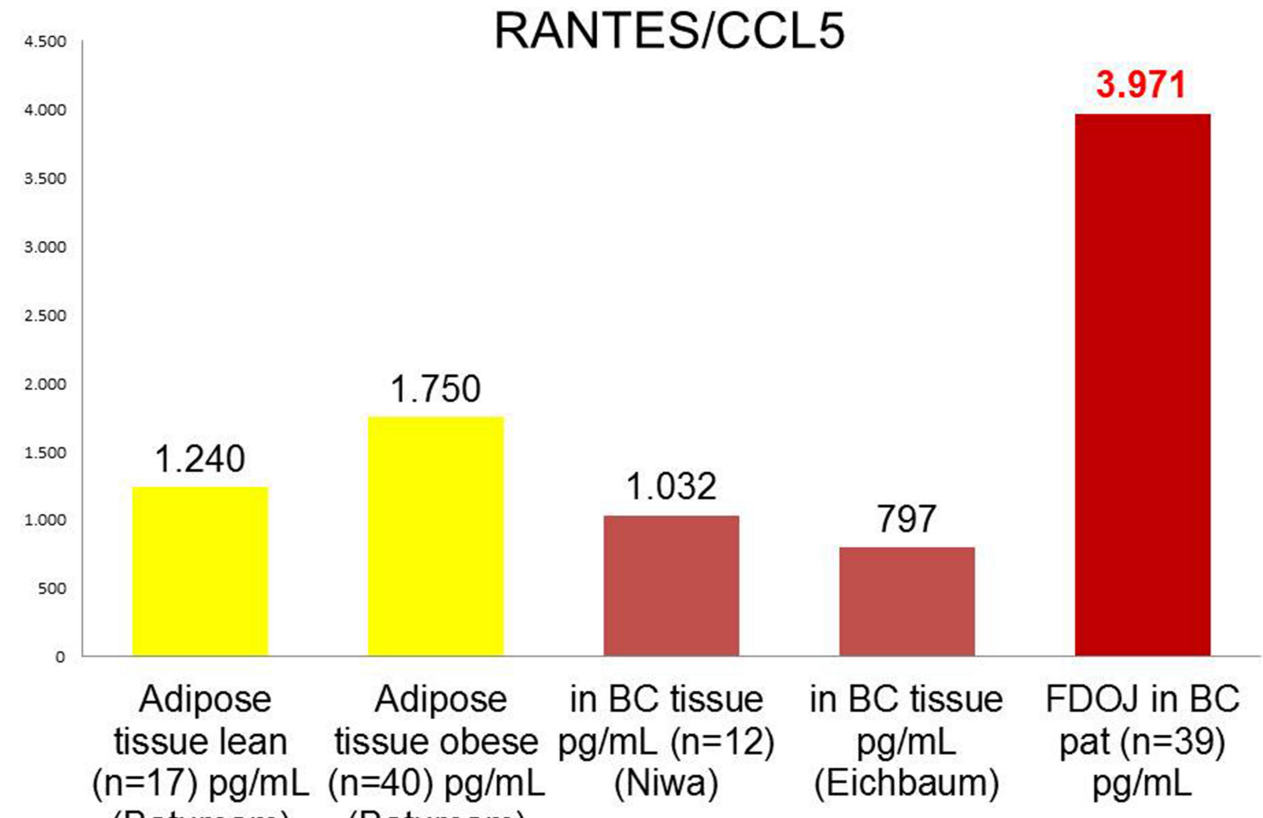

(Baturcam) (Baturcam)

Figure 13 Comparison of R/C expression in adipose tissue of healthy lean or obese people, in BC tissues (all data from literature) and in FDOJ in 39 BC patients.

(a) visceral adipocytes from body fat that deliver tumor necrosis factor (TNF)-a signals to MSCs and (b) to tumor-associated adipocytes in the tumor microenvironment. These deliver tumor-derived stem cells (TDSCs) for $\mathrm{R} / \mathrm{C}$ expression and tumor development. (c)
Adipocyte signaling does not arise from FDOJ via the usual TNF-a signaling but rather via $\mathrm{R} / \mathrm{C}$ overexpression. HSCs are converted to a myeloid derailment phenotype via autocrine and paracrine $\mathrm{R} / \mathrm{C}$ interactions, thus contributing to tumor development (Figure 14).
Body fat

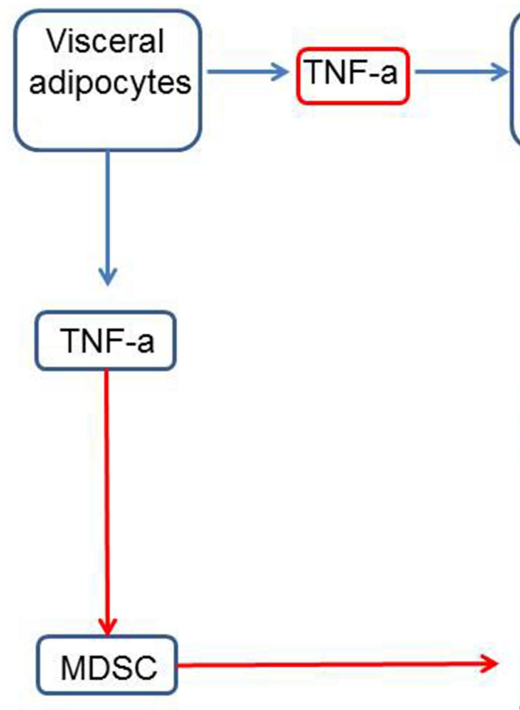

Tumor microenvironment

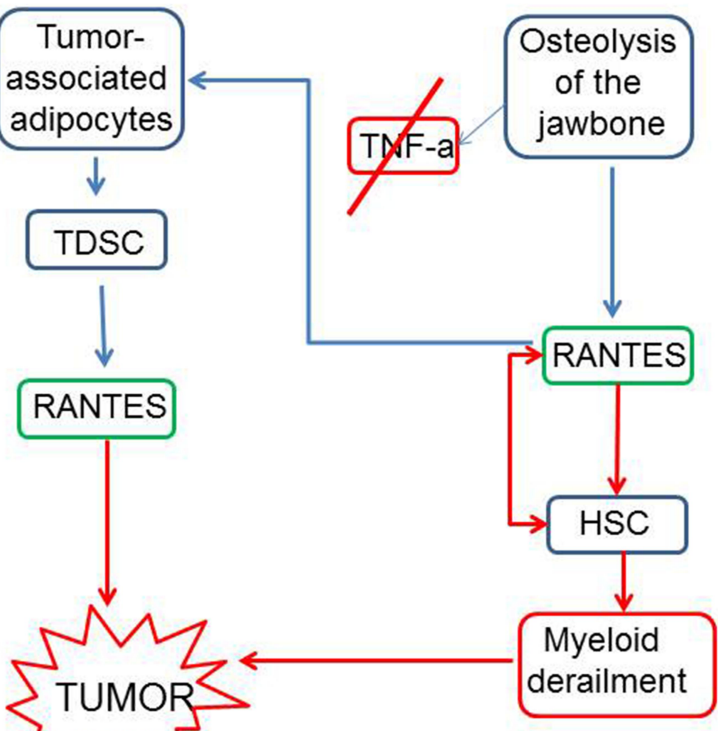

Figure 14 Adipocytes and systemic diseases: Three groups of adipocytes contribute to tumor development via different signaling pathways. Abbreviations: HSC, hematopoietic stem cell; MDSC, mesenchymal derived stem cell; TDSC, tumor-derived stem cell. 


\section{High Serum Levels of RANTES/CCL5}

Serve as an Indicator in Tumorigenesis and

Perpetuate Angiogenesis in the Tumor

Further research shows the potential use of chemokine R/C as a marker for progressive disease in BC. Evaluation of S-R/C expression could be used to identify patients with poor BC prognosis ${ }^{24}$ as poor cancer outcome is linked with high cytokine serum levels. ${ }^{52} \mathrm{R} / \mathrm{C}$ is associated with chronic inflammation and may play a direct role in angiogenesis ${ }^{55,56}$ and in the progression of some tumors may be due to R/C-mediated leukocyte recruitment and activation. ${ }^{53,54}$ Tumors are known to build blood vessels to promote growth and potential metastasis pathways. ${ }^{54}$ Tumors expressing low levels of $\mathrm{R} / \mathrm{C}$ showed a decrease in growth rate in vivo. Conversely, tumors expressing high levels of $\mathrm{R} / \mathrm{C}$ induce a decreased $\mathrm{T}$ cell response and upregulated matrix metalloproteinase 9 transcripts, which contribute to angiogenesis. ${ }^{56} \mathrm{R} / \mathrm{C}$ is secreted by aging fibroblasts, induces the proliferation of prostate epithelial cells, and the expression of genes associated with angiogenesis. ${ }^{57}$ These findings are important for the authors' hypothetical approach that by eliminating the $\mathrm{R} / \mathrm{C}$ signals originating from hidden FDOJ areas, tumor angiogenesis could be reduced. Thus, FDOJ surgery could potentially help in treating cancer and reducing metastases.

\section{Adipocytes in Tumor and in}

\section{Fatty-Degenerated Jawbone Marrow are} Sources of RANTES/CCL5 Expression

Literature provides evidence that adipocytes located close to invasive cancer cells, referred to as cancer-associated adipocytes (CAAs), ${ }^{58}$ are essential for breast tumor development/ progression. Mesenchymal stem cells (MSCs) are multipotent progenitor cells that are required for the regeneration of tissues such as cartilage, bone, adipose tissues, and muscle. ${ }^{59}$ These cells are mainly found in the bone marrow. When BC cells were co-cultured with MSC in vitro, it was found that the latter cells produce $\mathrm{R} / \mathrm{C}{ }^{28}$ The secretion of MSC-derived $\mathrm{R} / \mathrm{C}$ is driven by a positive-feedback loop. Namely, R/C and hypoxia stimulate $\mathrm{BC}$ cells to secrete colony-stimulating factor 1 (CSF1), which in turn promotes the increased production of R/C from MSCs. ${ }^{60}$

\section{RANTES/CCL5 and Breast Cancer Metastasis}

Metastatic lesions are significantly more difficult to treat and are usually a leading cause of death: $10-15 \%$ of BC patients with metastases die within three years of their first diagnosis ${ }^{64}$ with a life-long risk of developing metastases. ${ }^{65}$

Chemokines such as $\mathrm{R} / \mathrm{C}$ provide survival signals for malignant cells because their functional chemokine receptors can contribute to the metastatic activity. ${ }^{61}$ In a study where $\mathrm{BC}$ cells were made to overexpress $\mathrm{R} / \mathrm{C}$, it was found that the chemokine enhanced metastasis by increasing the motility and extravasation of cancer cells from the blood to a distant site in the body. ${ }^{62} \mathrm{R} / \mathrm{C}$, which is mainly produced by MSCs, along with epidermal growth factor ${ }^{63}$ promotes metastasis by triggering matrix metalloproteinases (MMP) production and improving cancer cell motility through a complex network of interacting factors and positive feedback loops. Obese patients present adipose tissue made of inflammatory cytokines and mediators secreting cells, prone at promoting cancer invasion and creating a metastasic environment. ${ }^{58,59}$

\section{Summary and Outlook}

The search for new diagnosis or prognosis targets or design of new therapeutic strategies is of great interest for cancer patients. Deciphering the molecular and cellular mechanisms between adipocytes and cancer cells is, therefore, of particular interest. Our understanding of the relationship between bone marrow metabolic disorders, cancer risk and/or poor patient outcomes would hence be of importance. As the metastatic properties of $\mathrm{BC}$ cells mediated by $\mathrm{R} / \mathrm{C}$ are only transiently upregulated and the metastatic phenotype is reversible, ${ }^{28}$ consequently, it could be challenging to detect the transient expression of molecules and phenotypes - like FDOJ-R/C overexpression that propagate $\mathrm{BC}^{25,60,65}$ As in essence, $\mathrm{R} / \mathrm{C}$ is a potentially useful target for the prevention of $\mathrm{BC}$ cancer metastases ${ }^{66,67}$ and as the metastatic phenotype might be reversible, ${ }^{28}$ the author's surgical elimination of continuous FDOJ-R/C signaling input could be a therapeutic option to avoid metastatic outcomes. Individual genetic susceptibility provided a permanently increased expression of R/C in FDOJ sites that could exert inflammatory signaling in breast tissue. Vice versa, the drainage of the source could limit inflammatory signaling. The author's research focuses on $\mathrm{R} / \mathrm{C}$ signaling pathways deriving from FDOJ areas. These pathways might initiate processes of cancer development and progression. Therefore, the authors' hypothesis follows the goal of FDOJ surgery to remove the fatty tissues in the jawbone, hence removing the source of $\mathrm{R} / \mathrm{C}$. The more researchers understand how tumors exploit signaling cascades, the more creatively dentists 
can target and intercept tumor growth, possibly in combination with FDOJ surgery.

\section{Limitations of the Study}

The size of the sample used in this cross-sectional study is very small, which is one of the major limitations of this study. The duration of FDOJ, underlying diseases, the use of drugs along with their dosage, as well as concomitant treatments, and multimorbidity are also limiting factors. By way of example, blood tests could only be performed once for each participant and at different times. However, two phenomena similar to those presented in breast cancer have been highlighted: $\mathrm{R} / \mathrm{C}$ overexpression and fatty degeneration of the jawbone (FDOJ - aseptic osteolysis). The results presented contribute to broaden the understanding of aseptic osteolysis of the jawbone by linking it to the epistemology of breast cancer, even if not providing sufficient evidence of causality and necessitating further investigations to clearly link FDOJ with breast cancer evolution or poor patient outcome.

\section{Conclusion - The Immune System - Bone Interactions in the New Field of "Maxillo-Mandibular Osteoimmunology"}

The current paper presents a compelling hypothesis on the role that tumorogenetic adipose tissues located in the jawbone may play due to their R/C expression. Authors could identify $\mathrm{R} / \mathrm{C}$, a chemokine that plays a key factor role within the area of "maxillo-mandibular osteoimmunology" in a cohort of 39 BC patients with FDOJ and has identified it as such in a new field of research in several papers. ${ }^{19,36,46,68,69}$ Osteoimmunology is an emerging field of research that studies the interactions between the immune and skeletal systems. Common R/C expression in FDOJ and BC tissues may be visualized with immunohistochemical staining. Authors have highlighted that $\mathrm{R} / \mathrm{C}$ is a particularly influential chemokine which expression regulates immune cell communication as well as bone cell regulation. It is also of major importance in the health of the skeleton. By presenting $\mathrm{R} / \mathrm{C}$ expression data in the jawbone medulla, the authors wish to help to develop a new understanding of bone marrow, hematopoietic, and immune system mode of actions. $\mathrm{R} / \mathrm{C}$ overexpression in FDOJ may be identified as a mechanism that proceeds in different immunological phases. ${ }^{21} \mathrm{R} / \mathrm{C}$ directly influences the decisions of stem cells, which result in the chronic and negative manipulation of hematopoiesis. ${ }^{48,59,60}$ This sheds new light on the role of fat cells in $\mathrm{BC}$ progression and could contribute to the development of new, more effective therapies, especially for the treatment of cancer patients with existing FDOJ. Collectively, the described findings open new insights underlying increased $\mathrm{BC}$ propensity in individuals with chronic FDOJ derived overexpression of $\mathrm{R} / \mathrm{C}$. The author's findings underline and suggest that approaches targeting the "FDOJ adipocyte R/C - cancer cell cross-talk" may help reduce cancer cell growth and cancer cell metastasis under an integrative aspect. Greater attention must be paid by medicine and dentistry to the hidden phenomenon of FDOJ and its associated signals for the benefit of patients who have breast cancer. The complete elucidation of complex interactions underlying these processes undoubtedly requires further research.

\section{Abbreviations}

$\mathrm{BC}$, breast cancer; CCL5, chemokine ligand 5; CCR5, chemokine receptor 5; CT, computed tomography; DVT, digital volume tomogram; HSC, hematopoietic stem cell; MSC, mesenchymal stem cell; OB, osteoblast; OK, osteoclast; OPG, orthopantomogram; R/C, RANTES/CCL518/19 = upper right wisdom tooth area (European Code on Dental Procedures and Nomenclature; US CDT code $=\# 1$ ); 38/39, lower left wisdom tooth area (US CDT code $=\# 24$ ).

\section{Disclosure}

Beatrice Lejeune is an employee of Labo'Life France. The authors report no other potential conflicts of interest for this work.

\section{References}

1. McAllister F, Bailey JM, Alsina J, et al. Oncogenic kras activates a hematopoietic-to-epithelial IL-17 signaling axis in preinvasive pancreatic neoplasia. Cancer Cell. 2014;25(5):621-637. doi:10.1016/j. ccr.2014.03.014

2. Kryczek I, Lin Y, Nagarsheth N, et al. IL-22(+)CD4(+) T cells promote colorectal cancer stemness via STAT3 transcription factor activation and induction of the methyltransferase DOT1L. Immunity. 2014;40(5):772-784. doi:10.1016/j.immuni.2014.03.010

3. Ferrarelli LK. Exosomes prep the metastatic site. Sci Signal. 2015;8 (380):ec150 LP-ec150. doi:10.1126/scisignal.aac7366

4. Khalid A, Wolfram J, Ferrari I, et al. Recent advances in discovering the role of CCL5 in metastatic breast cancer. Mini Rev Med Chem. 2015;15(13):1063-1072. doi:10.2174/138955751513150923094709

5. Park CC, Bissell MJ, Barcellos-Hoff MH. The influence of the microenvironment on the malignant phenotype. Mol Med Today. 2000;6 (8):324-329. doi:10.1016/S1357-4310(00)01756-1

6. Bonafe M, Storci G, Franceschi C. Inflamm-aging of the stem cell niche: breast cancer as a paradigmatic example: breakdown of the multi-shell cytokine network fuels cancer in aged people. Bioessays. 2012;34(1):40-49. doi:10.1002/bies.201100104 
7. Bieche I, Lerebours F, Tozlu S, Espie M, Marty M, Lidereau R. Molecular profiling of inflammatory breast cancer: identification of a poor-prognosis gene expression signature. Clin Cancer Res. 2004;10(20):6789-6795. doi:10.1158/1078-0432.CCR-04-0306

8. Kohlmeier JE, Miller SC, Smith J, et al. The chemokine receptor CCR5 plays a key role in the early memory CD8+ T cell response to respiratory virus infections. Immunity. 2008;29(1):101-113. doi:10.10 16/j.immuni.2008.05.011

9. Schall TJ, Bacon K, Toy KJ, Goeddel DV. Selective attraction of monocytes and $\mathrm{T}$ lymphocytes of the memory phenotype by cytokine RANTES. Nature. 1990;347(6294):669-671. doi:10.1038/347669a0

10. Lin C-L, Suri RM, Rahdon RA, Austyn JM, Roake JA. Dendritic cell chemotaxis and transendothelial migration are induced by distinct chemokines and are regulated on maturation. Eur J Immunol. 1998;28(12):4114-4122. doi:10.1002/(SICI)1521-4141(199812)28: 12<4114::AID-IMMU4114>3.0.CO;2-C

11. Romagnani S. Cytokines and chemoattractants in allergic inflammation. Mol Immunol. 2002;38(12-13):881-885. doi:10.1016/ S0161-5890(02)00013-5

12. Velasco-Velazquez M, Pestell RG. The CCL5/CCR5 axis promotes metastasis in basal breast cancer. Oncoimmunology. 2013;2(4):e23 660. doi:10.4161/onci.23660

13. Wertel I, Tarkowski R, Bednarek W, Kotarski J. Relationship between RANTES and dendritic cells in ovarian cancer patients. Front Biosci. 2011;3:227-232. doi:10.2741/e237

14. Vaday GG, Peehl DM, Kadam PA, Lawrence DM. Expression of CCL5 (RANTES) and CCR5 in prostate cancer. Prostate. 2006;66 (2):124-134. doi:10.1002/pros.20306

15. Monti P, Marchesi F, Reni M, et al. A comprehensive in vitro characterization of pancreatic ductal carcinoma cell line biological behavior and its correlation with the structural and genetic profile. Virchows Arch. 2004;445(3):236-247. doi:10.1007/s00428-00 4-1053-x

16. Mrowietz U, Schwenk U, Maune S, et al. The chemokine RANTES is secreted by human melanoma cells and is associated with enhanced tumour formation in nude mice. Br J Cancer. 1999;79(7-8):1025-1031. doi:10.1038/sj.bjc. 6690164

17. Lechner J. Validation of dental X-ray by cytokine RANTES - comparison of X-ray findings with cytokine overexpression in jawbone. Clin Cosmet Investig Dent. 2014;6:71-79. doi:10.2147/CCIDE. S69807

18. Bouquot J, Shankland WI, Margolis M. Through-transmission alveolar ultrasonography (TAU) - new technology for evaluation of bone density and desiccation. Comparison with radiology of 170 biopsied alveolar sites of osteoporotic and ischemic damage. Oral Surg Oral Med Oral Pathol Oral Radiol Endod. 2002;93:413-414.

19. Lechner J, von Baehr V. RANTES and fibroblast growth factor 2 in jawbone cavitations: triggers for systemic disease? Int J Gen Med. 2013;6:277-290. doi:10.2147/IJGM.S43852

20. von Luettichau I, Nelson PJ, Pattison JM, et al. RANTES chemokine expression in diseased and normal human tissues. Cytokine. 1996;8 (1):89-98. doi:10.1006/cyto.1996.0012

21. Lechner J, Schulz T, von Baehr V. Immunohistological staining of unknown chemokine RANTES/CCL5 expression in jawbone marrow defects - osteoimmunology and disruption of bone remodeling in clinical case studies targeting on predictive preventive personalized medicine. EPMA J. 2019;10(4):351-364. doi:10.1007/s13167-019-00182-1

22. Soria G, Ben-Baruch A. The inflammatory chemokines CCL2 and CCL5 in breast cancer. Cancer Lett. 2008;267(2):271-285. doi:10. 1016/j.canlet.2008.03.018

23. Niwa Y, Akamatsu H, Niwa H, Sumi H, Ozaki Y, Abe A. Correlation of tissue and plasma RANTES levels with disease course in patients with breast or cervical cancer. Clin Cancer Res. 2001;7(2):285-289.

24. Wigler N, Shina S, Kaplan O, et al. Breast carcinoma: a report on the potential usage of the $\mathrm{CC}$ chemokine RANTES as a marker for a progressive disease. Isr Med Assoc J. 2002;4(11 Suppl):940-943.
25. Zhang Y, Lv D, Kim H-J, et al. A novel role of hematopoietic CCL5 in promoting triple-negative mammary tumor progression by regulating generation of myeloid-derived suppressor cells. Cell Res. 2013;23 (3):394-408. doi:10.1038/cr.2012.178

26. Luboshits G, Shina S, Kaplan O, et al. Elevated expression of the CC chemokine regulated on activation, normal $\mathrm{T}$ cell expressed and secreted (RANTES) in advanced breast carcinoma. Cancer Res. 1999;59(18):4681-4687.

27. Laslo P, Spooner CJ, Warmflash A, et al. Multilineage transcriptional priming and determination of alternate hematopoietic cell fates. Cell. 2006;126(4):755-766. doi:10.1016/j.cell.2006.06.052

28. Karnoub AE, Dash AB, Vo AP, et al. Mesenchymal stem cells within tumour stroma promote breast cancer metastasis. Nature. 2007;449 (7162):557-563. doi:10.1038/nature06188

29. Ferlay J, Soerjomataram I, Dikshit R, et al. Cancer incidence and mortality worldwide: sources, methods and major patterns in GLOBOCAN 2012. Int $J$ Cancer. 2015;136(5):E359-E386. doi:10. $1002 / \mathrm{ijc} .29210$

30. Gregor MF, Hotamisligil GS. Inflammatory mechanisms in obesity. Annu Rev Immunol. 2011;29(1):415-445. doi:10.1146/annurevimmunol-031210-101322

31. Osborn O, Olefsky JM. The cellular and signaling networks linking the immune system and metabolism in disease. Nat Med. 2012;18 (3):363-374. doi: $10.1038 / \mathrm{nm} .2627$

32. Duong MN, Cleret A, Matera E-L, et al. Adipose cells promote resistance of breast cancer cells to trastuzumab-mediated antibody-dependent cellular cytotoxicity. Breast Cancer Res. 2015; 17(1):57. doi:10.1186/s13058-015-0569-0

33. Eichbaum C, Meyer A-S, Wang N, et al. Breast cancer cell-derived cytokines, macrophages and cell adhesion: implications for metastasis. Anticancer Res. 2011;31(10):3219-3227.

34. Baturcam E, Abubaker J, Tiss A, et al. Physical exercise reduces the expression of RANTES and its CCR5 receptor in the adipose tissue of obese humans. Mediators Inflamm. 2014;2014:627150. doi:10.11 $55 / 2014 / 627150$

35. Xiong Y, Russell DL, McDonald LT, Cowart LA, LaRue AC. Hematopoietic stem cell-derived adipocytes promote tumor growth and cancer cell migration. Int J Cancer Res Mol Mech. 2017;3(1). doi:10.16966/2381-3318.130

36. Lechner J, von Baehr V. Hyperactivated signaling pathways of chemokine RANTES/CCL5 in osteopathies of jawbone in breast cancer patients-case report and research. Breast Cancer (Auckl). 2014; 8:89-96. doi:10.4137/BCBCR.S15119

37. Nieman KM, Romero IL, Van Houten B, Lengyel E. Adipose tissue and adipocytes support tumorigenesis and metastasis. Biochim Biophys Acta. 2013;1831(10):1533-1541. doi:10.1016/j.bbalip.2013.02.010

38. Carroll PA, Healy L, Lysaght J, et al. Mammary adipose tissue and cancer cell growth: the role of adipose tissue in the tumor microenvironment. J Clin Oncol. 2009;27(15_suppl):e22009e22009. doi:10.1200/jco.2009.27.15_suppl.e22009

39. Andarawewa KL, Motrescu ER, Chenard M-P, et al. Stromelysin-3 is a potent negative regulator of adipogenesis participating to cancer cell-adipocyte interaction/cross-talk at the tumor invasive front. Cancer Res. 2005;65(23):10862-10871. doi:10.1158/0008-5472.CAN-05-1231

40. Iyengar P, Combs TP, Shah SJ, et al. Adipocyte-secreted factors synergistically promote mammary tumorigenesis through induction of anti-apoptotic transcriptional programs and proto-oncogene stabilization. Oncogene. 2003;22(41):6408-6423. doi:10.1038/sj.onc. 1206737

41. Zischek C, Niess H, Ischenko I, et al. Gezielte stammzellbasierte RANTES/Tk Suizidgentherapie des murinen Pankreaskarzinoms [Targeted stem cell based RANTES/TK suicide gene-therapy in a murine pancreatic cancer tumour model]. In: Schumpelick V, Bruch HP, Schackert HK, editors. Deutsche Gesellschaft für Chirurgie [German Society for Surgery], vol 38. Heidelberg: Springer, Berlin; 2009. German. doi:10.1007/978-3-642-00625-8_2 
42. Yaal-Hahoshen N, Shina S, Leider-Trejo L, et al. The chemokine CCL5 as a potential prognostic factor predicting disease progression in stage II breast cancer patients. Clin Cancer Res. 2006;12 (15):4474-4480. doi:10.1158/1078-0432.CCR-06-0074

43. Crossno JTJ, Majka SM, Grazia T, Gill RG, Klemm DJ. Rosiglitazone promotes development of a novel adipocyte population from bone marrow-derived circulating progenitor cells. J Clin Invest. 2006;116(12):3220-3228. doi:10.1172/JCI28510

44. Tomiyama K, Murase N, Stolz DB, et al. Characterization of transplanted green fluorescent protein + bone marrow cells into adipose tissue. Stem Cells. 2008;26(2):330-338. doi:10.1634/stemcells.2007-0567

45. Sera Y, LaRue AC, Moussa O, et al. Hematopoietic stem cell origin of adipocytes. Exp Hematol. 2009;37(9):1108-1120, 1120.e1-4. doi:10.1016/j.exphem.2009.06.008

46. Lechner J, von Baehr V. Chemokine RANTES/CCL5 as an unknown link between wound healing in the jawbone and systemic disease: is prediction and tailored treatments in the horizon? EPMA J. 2015;6 (1):10. doi:10.1186/s13167-015-0032-4

47. Rosen ED, Spiegelman BM. What we talk about when we talk about fat. Cell. 2014;156(1-2):20-44. doi:10.1016/j.cell.2013.12.012

48. Liu S, Dontu G, Wicha MS. Mammary stem cells, self-renewal pathways, and carcinogenesis. Breast Cancer Res. 2005;7(3):86-95. doi:10.1186/bcr1021

49. Picon-Ruiz M, Pan C, Drews-Elger K, et al. Interactions between adipocytes and breast cancer cells stimulate cytokine production and drive Src/Sox2/miR-302b-mediated malignant progression. Cancer Res. 2016;76(2):491-504. doi:10.1158/0008-5472.CAN-15-0927

50. Bromberg J, Wang TC. Inflammation and cancer: IL-6 and STAT3 complete the link. Cancer Cell. 2009;15(2):79-80. doi:10.1016/j. ccr.2009.01.009

51. Floris I, Lechner J, Lejeune B. Follow-up of patients with systemic immunological diseases undergoing fatty-degenerative osteolysis of the jawbone surgery and treated with RANTES 27CH. J Biol Regul Homeost Agents. 2018;32(1):37-45.

52. Nicolini A, Carpi A, Rossi G. Cytokines in breast cancer. Cytokine Growth Factor Rev. 2006;17(5):325-337. doi:10.1016/j.cytogfr.2006.07.002

53. Marques RE, Guabiraba R, Russo RC, Teixeira MM. Targeting CCL5 in inflammation. Expert Opin Ther Targets. 2013;17(12):1439-1460. doi:10.1517/14728222.2013.837886

54. Bussolino F, Mantovani A, Persico G. Molecular mechanisms of blood vessel formation. Trends Biochem Sci. 1997;22(7):251-256. doi:10.1016/S0968-0004(97)01074-8

55. Suffee N, Hlawaty H, Meddahi-Pelle A, et al. RANTES/CCL5-induced proangiogenic effects depend on CCR1, CCR5 and glycosaminoglycans. Angiogenesis. 2012;15(4):727-744. doi:10.1007/s10456-012-9285-X

56. Ambati BK, Anand A, Joussen AM, Kuziel WA, Adamis AP, Ambati J. Sustained inhibition of corneal neovascularization by genetic ablation of CCR5. Invest Ophthalmol Vis Sci. 2003;44 (2):590-593. doi:10.1167/iovs.02-0685
57. Eyman D, Damodarasamy M, Plymate SR, Reed MJ. CCL5 secreted by senescent aged fibroblasts induces proliferation of prostate epithelial cells and expression of genes that modulate angiogenesis. J Cell Physiol. 2009;220(2):376-381. doi:10.1002/ jcp. 21776

58. Tan J, Buache E, Chenard M-P, Dali-Youcef N, Rio M-C. Adipocyte is a non-trivial, dynamic partner of breast cancer cells. Int J Dev Biol. 2011;55(7-9):851-859. doi:10.1387/ijdb.113365jt

59. Pittenger MF, Mackay AM, Beck SC, et al. Multilineage potential of adult human mesenchymal stem cells. Science. 1999;284 (5411):143-147. doi:10.1126/science.284.5411.143

60. Chaturvedi P, Gilkes DM, Takano N, Semenza GL. Hypoxiainducible factor-dependent signaling between triple-negative breast cancer cells and mesenchymal stem cells promotes macrophage recruitment. Proc Natl Acad Sci US A. 2014;111(20):E2120-9. doi:10.1073/pnas.1406655111

61. White GE, Iqbal AJ, Greaves DR. CC chemokine receptors and chronic inflammation - therapeutic opportunities and pharmacological challenges. Pharmacol Rev. 2013;65(1):47-89. doi:10.1124/ pr.111.005074

62. Zlotnik A, Burkhardt AM, Homey B. Homeostatic chemokine receptors and organ-specific metastasis. Nat Rev Immunol. 2011;11 (9):597-606. doi:10.1038/nri3049

63. Mi Z, Bhattacharya SD, Kim VM, Guo H, Talbot LJ, Kuo PC. Osteopontin promotes CCL5-mesenchymal stromal cell-mediated breast cancer metastasis. Carcinogenesis. 2011;32(4):477-487. doi:10.1093/carcin/bgr009

64. Weigelt B, Peterse JL, van 'T Veer LJ. Breast cancer metastasis: markers and models. Nat Rev Cancer. 2005;5(8):591-602. doi:10. $1038 /$ nrc 1670

65. Mathot L, Stenninger J. Behavior of seeds and soil in the mechanism of metastasis: a deeper understanding. Cancer Sci. 2012;103 (4):626-631. doi:10.1111/j.1349-7006.2011.02195.x

66. Kotyza J. Chemokines in tumor proximal fluids. Biomed Pap Med Fac Univ Palacky Olomouc Czech Repub. 2017;161(1):41-49. doi: $10.5507 / \mathrm{bp} .2016 .062$

67. Balkwill F. Cancer and the chemokine network. Nat Rev Cancer. 2004;4(7):540-550. doi:10.1038/nrc1388

68. Lechner J, Huesker K, Von Baehr V. Impact of rantes from jawbone on chronic fatigue syndrome. J Biol Regul Homeost Agents. 2017;31 (2):321-327.

69. Lechner J, Schuett S, von Baehr V. Aseptic-avascular osteonecrosis: local "silent inflammation" in the jawbone and RANTES/CCL5 overexpression. Clin Cosmet Investig Dent. 2017;9:99-109. doi:10.2147/ CCIDE.S149545
Breast Cancer: Targets and Therapy

\section{Publish your work in this journal}

Breast Cancer - Targets and Therapy is an international, peer-reviewed open access journal focusing on breast cancer research, identification of therapeutic targets and the optimal use of preventative and integrated treatment interventions to achieve improved outcomes, enhanced survival and quality of life for the cancer patient.
The manuscript management system is completely online and includes a very quick and fair peer-review system, which is all easy to use. Visit http://www.dovepress.com/testimonials.php to read real quotes from published authors. 